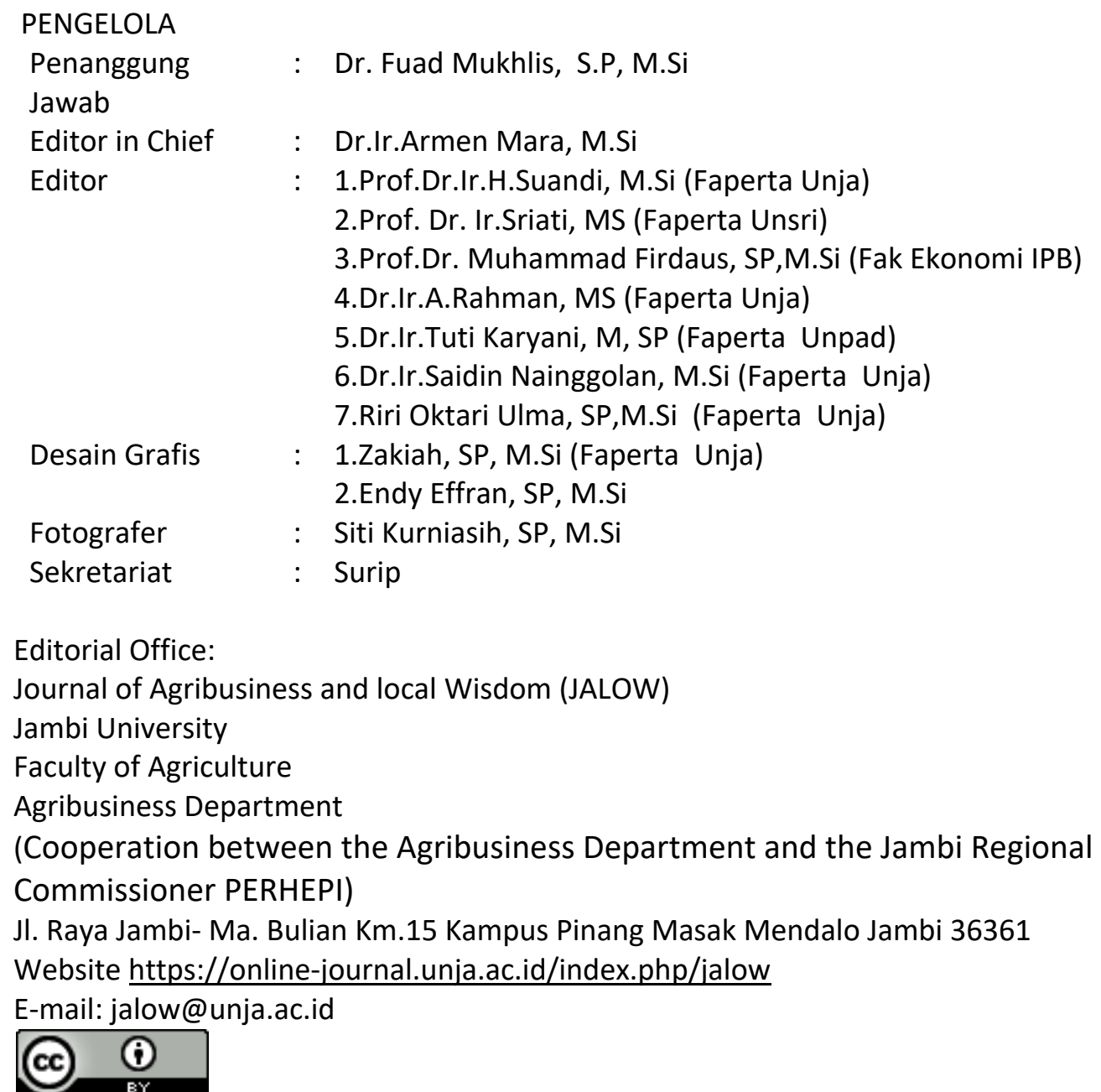

This work is licensed under a Creative Commons Attribution 4.0 International License. 


\section{Assalamualaikum wbwb}

\section{PENGANTAR}

Kondisi agribisnis tahun 2020 ini agak berbeda dengan tahun sebelumnya. Kebijakan penanggulangan Covid19 seperti "dirumah Aja, lockdown lokasi, Isolasi Mandiri, PSBB (Pembatasan Sosial Berskala Besar), dan Herd Immunity" telah merubah pola aktivitas masyarakat, khususnya di Kota-kota. Sebelumnya, berkejar2an dengan waktu untuk meningkatkan pendapatan dengan jalan menambah produktivitas dan menekan biaya telah dikagetkan oleh adanya ancaman pandemi Covid19 yang ada dimana-mana, semangat berkejar-kejaran tersebut kendur seketika.

Kegiatan perdagangan di Kota-kota besar maupun kota kecil telah mengalami kelesuan untuk semua lapisan, mulai dari pedagang kecil mikro, pedagang asongan atau gerobak, pedagang toko, mini market sampai perdagangan berskala besar, super market, dan mallmall. Hal ini menyebabkan terjadinya pengangguran, berkurangnya pendapatan masyarakat dan menurun drastisnya penerimaan pemerintah dari pajak. Selama masa isolasi, para konsumen melakukan belanja dengan sangat hati-hati. Pihak produsen merasakan berkurangnya permintaan. Oleh karena itu, walaupun kebijakan Covid19 tidak menghambat aktivitas produksi pertanian di lahan secara langsung namun karena permintaan berkurang maka berkurang pula pendapatan petani yang mengusahakan kebun atau sawah.

Kebiasaan konsumen yang selama ini lebih banyak makan di luar rumah berubah menjadi lebih banyak makan di rumah sendiri, masak sendiri atau pesan antar. Berbelanja yang semula mencari tempat2 yang banyak di kerumuni orang berubah ke tempat yang tidak ada kerumunannya, artinya rasa enak dan harga murah tidak lagi menjadi patokan utama bagi konsumen. Mereka lebih mengutamakan sehat dan terjamin dalam proses pembuatannya. Kesadaran adanya ancaman bahaya serangan Covid19 terhadap nyawa setiap orang telah menyebabkan berubah nya psikologi dan sosial masyarakat. Sebelumnya berpikir materialis dan untung rugi dari setiap kerja, sekarang mulai nampak adanya kepedulian terhadap perintah agama melaksanakan sholat dan bersedekah. Mulai terlihat adanya aktivitas sosial di tengah-tengah kota, ada kegiatan membagikan nasi bungkus kepada kaum duafah dan lapisan bawah, kegiatan membagikan sembako, membagikan ampelop berisi uang kertas, sampai pada aktivitas memberikan tip berupa uang dalam setiap kali berbelanja di pedagang-pedagang kecil.

Harapan untuk semua aktivitas-aktivitas positif tersebut berlangsung tidak sementara tapi menjadi karakter bagi setiap orang. Kalau aktivitas sosial ini terus dipertahankan oleh pelaku yang telah memulai nya tentu akan diikuti juga oleh yang lainnya. Diharapkan juga setiap pelaku agribisnis berskala kecil, baik yang disektor produksi pertanian maupun sektor industri pengolahan dan perdagangan dapat mengantisipasi perubahan prilaku konsumen tersebut dengan perubahan pola produksi yang sesuai sehingga peluang bisnis yang terlepas dari pola sebelumnya dapat ditangkap.

Demikian semoga JALOW untuk penerbitan ini bermanfaat untuk kita semua aamiin ya robbal aalamiin.

Waalaikumsalam wbwb

Editor in Chief

Dr.Ir.Armen Mara,M.Si 
DAFTAR ISI

\begin{tabular}{|c|c|c|}
\hline 1 & $\begin{array}{l}\text { ANALISIS RESPON PENAWARAN KOMODITI KEDELAI } \\
\text { DI KABUPATEN TANJAB TIMUR } \\
\text { Oleh Edison }\end{array}$ & $1-10$ \\
\hline 2 & 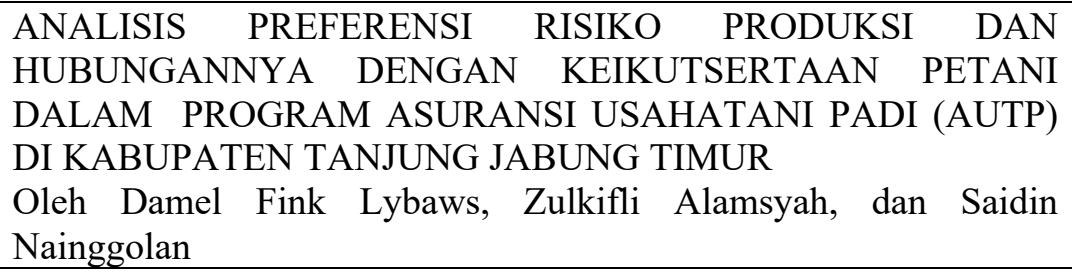 & $11-27$ \\
\hline 3 & $\begin{array}{l}\text { ANALISIS USAHA IKAN HIAS AIR TAWAR DI KOTA JAMBI (ANALYSIS } \\
\text { OF FRESH WATER ORNAMENTAL FISH IN JAMBI CITY) } \\
\text { Dody Hadisaputra, Ernawati, Suandi }\end{array}$ & $28-40$ \\
\hline 4 & $\begin{array}{l}\text { ANALISIS FAKTOR-FAKTOR YANG MEMPENGARUHI PRODUKSI } \\
\text { BOKAR (BAHAN OLAH KARET) DI KABUPATEN BATANGHARI } \\
\text { Oleh Elisabeth Lumban Gaol, Armen Mara, dan Riri Oktari UIma }\end{array}$ & $41-52$ \\
\hline 5 & $\begin{array}{l}\text { ANALISIS PENGAMBILAN KEPUTUSAN UNTUK PEMBELIAN } \\
\text { MAKANAN KEMASAN BERLOGO HALAL MUI (STUDI KASUS IBU } \\
\text { RUMAH TANGGA DI PERUMAHAN AUR DURI DAN PERUMNAS KOTA } \\
\text { BARU, KOTA JAMBI) } \\
\text { Oleh Putri Hana Jusia, Saad Murdy, Lavlinesia }\end{array}$ & $53-66$ \\
\hline 6 & \begin{tabular}{lrrrr} 
STRATEGI & ADAPTASI & PETANI & DALAM & \multicolumn{2}{l}{ MENGHADAPI } \\
RENDAHNYA & HARGA & JUAL & KELAPA & SAWIT DI \\
KECAMATAN & SUNGAI & BAHAR & KABUPATEN & MUARO \\
JAMBI & & & \\
Oleh Fiona Andini & ), Fuad Muchlis $^{2}$ ), Aulia Farida 2) \\
\end{tabular} & $67-73$ \\
\hline 7 & \begin{tabular}{lcllr}
\multicolumn{2}{l}{ KOLABORASI } & DALAM & PENGELOLAAN & \multicolumn{2}{c}{ PERKEBUNAN } \\
KELAPA SAWIT & RAKYAT & (STUDI KASUS: KUD & LUBUK \\
KARYA DAN & KUD & KAMPUNG & SURAU & KAB. \\
DHARMASRAYA & & & & \\
Oleh Yulistriani & & & & \\
\end{tabular} & $74-81$ \\
\hline 8 & $\begin{array}{l}\text { KEPUTUSAN PETANI SAWIT DALAM MENGKONVERSI } \\
\text { LAHAN KELAPA SAWIT MENJADI LAHAN PADI SAWAH DI } \\
\text { KECAMATAN BATANG ASAM KABUPATEN } \\
\text { TANJUNG JABUNG BARAT } \\
\text { Oleh Krielson Ompusunggu1), Arsyad Lubis2, Siti Kurniasih2 }\end{array}$ & $82-88$ \\
\hline 9 & $\begin{array}{l}\text { KAITAN BIAYA DAN TEKNIK PEREMAJAAN } \\
\text { KELAPA SAWIT RAKYAT } \\
\text { Oleh Nur Imdah Minsyah }\end{array}$ & $89-99$ \\
\hline 10 & $\begin{array}{l}\text { STRATEGI RANTAI PASOK KELAPA SAWIT DI PROVINSI } \\
\text { SUMATERA BARAT } \\
\text { Oleh Rahma Dzulqa1*), Rika Ampuh Hadiguna2) }\end{array}$ & 100 \\
\hline
\end{tabular}




\title{
KOLABORASI DALAM PENGELOLAAN PERKEBUNAN KELAPA SAWIT RAKYAT (STUDI KASUS: KUD LUBUK KARYA DAN KUD KAMPUNG SURAU KAB. DHARMASRAYA
}

\author{
Yulistriani \\ Fakultas Pertanian Universitas Andalas \\ email: yulistrianidarlis87@gmail.com
}

\begin{abstract}
Palm oil is an export commodity that has an important role in the people's economy. Plasma patterns often experience problems after being released from large plantations. Cooperation between oil palm business actors influences the development of the people's oil palm business, especially in Dharmasraya Regency. This study aims to look at the impact of the development of smallholder oil palm plantations on the economic development of rural communities (case study: KUD Lubuk Karya and KUD Kampung Surau). The method used in this research is descriptive qualitative method. Data obtained through in-depth interviews with key informants.

The results showed that the KUD Lubuk Karya had a greater influence on the economy of the village community. Collaboration with the principle of justice, a common understanding of the responsibilities of each party strengthens the existence of the KUD in accelerating village development. It is necessary to evaluate, innovate and provide optimal assistance for the sustainable development of smallholder palm oil plantations.
\end{abstract} Keywords: smallholder, palm oil, plantations

\section{PENDAHULUAN}

Sektor pertanian mempunyai peranan penting dalam meningkatkan pendapatan masyarakat desa (alwarritzi et al., 2015). Kelapa sawit merupakan salah satu komoditas yang memiliki andil besar dalam menghasilkan pendapatan asli daerah, Produk Domestik Bruto (PDB), dan kesejahteraan masyarakat. Pembangunan perkebunan kelapa sawit memberikan tetesan manfaat (trickle effect), sehingga dapat memperluas daya penyebaran (power of dispersion) pada masyarakat sekitarnya. Semakin berkembangnya perkebunan kelapa sawit, semakin terasa dampaknya terhadap tenaga kerja (Syahza, 2011, Afifuddin, 2007) yang bekerja pada sektor perkebunan dan sektor turunannya. Dampak tersebut dapat dilihat dari peningkatan pendapatan masyarakat petani, sehingga meningkatnya daya beli masyarakat pedesaan, baik untuk kebutuhan primer maupun kebutuhan sekunder (Syahza, 2011).

Perkebunan kelapa sawit di Indonesia berdasarkan data dari Direktorat Jenderal Perkebunan dikelompokkan menjadi 3 jenis, yaitu Perkebunan Rakyat 
(PR)/ smallholder, Perkebunan Besar Negara (PBN)/ Government, Perkebunan Besar Swasta (PBS)/ Private. Menurut status pengusahaannya, sebagian besar perkebunan kelapa sawit pada tahun 2016 diusahakan oleh perkebunan besar swasta 51,37 \%, diusahakan oleh perkebunan rakyat sebesar $42,31 \%$, dan diusahakan oleh perkebunan besar negara sebesar 6,32\%. Areal perkebunan kelapa sawit tersebar di 25 provinsi yaitu seluruh provinsi di Pulau Sumatera dan Kalimantan, Provinsi Jawa Barat, Banten, Sulawesi Tengah, Sulawesi Selatan, Sulawesi Tenggara, Sulawesi Barat, Gorontalo, Maluku, Papua dan Papua Barat ( Badan Pusat Statistik Indonesia, 2017).

Kolaborasi adalah proses interaksi seseorang dengan orang lainnya dalam rangka melaksanakan proses pembelajaran (Dillenbourg, 1999) untuk memperbaiki pengetahuan bersama (Roschelle (1992), dengan kata lain kolaborasi adalah sebuah kegiatan yang terkoordinasi, terus membangun dan berupaya untuk memecahkan masalah bersama (Roschelle dan Teasley (1995). Kemampuan belajar seseorang berbeda-beda, dengan kolaborasi kemampuan tinggi dapat melakukan pembimbingan kepada yang mempunyai kemampuan lemah (Tugde, 1992, Saner et al. 1994). Kolaborasi adalah sebuah proses saling mengisi/melengkapi satu sama lain (Webb, 1991).

Di perkebunan sawit rakyat, permasalahan yang sering dihadapi antara lain rendahnya produktivitas dan mutu produksinya. Produktivitas tanaman kelapa sawit dipengaruhi oleh beberapa faktor, yaitu faktor lingkungan, faktor genetik, dan teknik budidaya tanaman. Faktor lingkungan (enforce) yang mempengaruhi produktivitas kelapa sawit meliputi faktor abiotik (curah hujan, hari hujan, tanah, topografi) dan faktor biotik (gulma, hama, jumlah populasi tanaman/ha). Faktor genetik (innate) meliputi varietas bibit yang digunakan dan umur tanaman kelapa sawit. Faktor teknik budidaya (induce) meliputi pemupukan, konservasi tanah dan air, pengendalian gulma, hama, dan penyakit tanaman, serta kegiatan pemeliharaan lainnya. Faktor-faktor tersebut saling berhubungan dan mempengaruhi satu sama lain (Pahan 2010).

Berdasarkan uraian yang disampaikan diatas, maka dapat disimpulkan rumusan masalah dari penelitian ini adalah : bagaimana peran kolaborasi dalam pengelolaan perkebunan kelapa sawit rakyat sehingga mendorong percepatan pembangunan desa. Penelitian ini bertujuan untuk melihat dampak pengembangan perkebunan kelapa sawit rakyat terhadap pembangunan perekonomian masyarakat desa (studi kasus: KUD Lubuk Karya dan KUD Kampung Surau). 


\section{METODE PENELITIAN}

Penelitian ini telah dilaksanakan di Kabupaten Dharamasraya pada dua KUD (Koperasi Unit Desa) yang bergerak diperkebunan kelapa Sawit yaitu KUD Kampung Surau (Jorong Kampung Surau Kenagarian Gunung Selasih, Kecamatan Pulau Punjung) dan KUD Lubuk Karya (Jorong Koto Agung, Kenagarian Koto Tinggi, Kecamatan Koto Besar. Penelitian ini dilaksanakan pada bulan Juli 2019 sampai dengan bulan September 2019.

Metode penelitian ini adalah deskriptif kualitatif melalui survey dan wawancara langsung. Wawancara dilakukan dalam dua tahapan. Pertama wawancara kepada informan kunci dari KUD Kampung Surau dan KUD Lubuk Karya. Kemudian wawancara dilanjutkan kepada petani yang tergabung ke dalam KUD Kampung Surau sebanyak 10 orang petani dan KUD Lubuk Karya sebanyak 10 orang petani. Wawancara dilakukan dengan bantuan kuisioner, 100 pertanyaan untuk informan kunci dan 26 pertanyaan untuk petani. Ini bertujuan untuk mendapatakn informasi yang akurat dari pihak manajemen dan anggota KUD.

Data hasil wawancara dari masing-masing KUD (KUD Kampung Surau dan KUD Lubuk Karya) ditabulasi kemudian diinterprestasikan dan dideskripsikan. Data dianalisa secara deskriptif kualitatif dengan mempertimbangkan beberapa aspek yang mempengaruhi pengelolaan perkebunan rakyat khususnya kebun plasma. Pengelolaan diidentifikasi mulai dari penyediaan saprodi sampai kepada panen dan pemasaran hasil panen. Kemudian dianalisis secara mendalam bagaimana konsep kolaborasi digunakan pada masing-masing aspek yang mempengaruhi pengelolaan kebun rakyat tersebut dan bagaimana perkembangan usaha dari masing-masing KUD tersebut.

\section{HASIL DAN PEMBAHASAN}

\section{Gambaran Umum Lokasi Penelitian}

Kabupaten Dharmasraya dengan ibukota Pulau Punjung adalah salah satu kabupaten di Sumatera Barat yang berada di persimpangan Jalur Lintas Sumatera yang menghubungkan antara Padang, Pekanbaru hingga Jambi. Terletak di ujung tenggara Sumatera Barat antara 00 47' 7" LS - 10 41' 56" LS \& 1010 9' 21" BT 1010 54' 27" BT. Kondisi dan topografi Kabupaten Dharmasraya mayoritas merupakan lahan datar dengan ketinggian dari 82 meter sampai 1.525 meter dari permukaan laut. Sebelah Utara Kabupaten Dharmasraya berbatasan dengan Kabupaten Sijunjung dan Provinsi Riau, sebelah Selatan dan di sebelah Timur berbatasan dengan Propinsi Jambi sedangkan di sebelah Barat dengan Kabupaten Solok dan Kabupaten Solok Selatan.

Kabupaten Dharmasraya merupakan salah satu kabupaten yang cukup berpotensi di Propinsi Sumatera Barat. Luas wilayah Kabupaten Dharmasraya 
berdasarkan Perda No. 10 Tahun 2012 yaitu 3.025,99 km² (302.599 Ha). Sebagian besar penggunaan lahan di Kabupaten Dharmasraya adalah untuk sektor pertanian hingga mencapai 87,31 persen dimana lahan perkebunan adalah yang terbesar mencapai 58,01 persen (Badan Pusat Statistik Dharmasraya, 2018).

\section{Profil Petani Anggota KUD}

Hasil wawancara kepada petani anggota KUD ditabulasikan ke dalam tabel 1 sebagai berikut:

Tabel 1. Profil Petani, Anggota KUD Lubuk Karya dan KUD Kampung Surau

\begin{tabular}{|c|c|c|c|c|}
\hline $\begin{array}{l}\text { Respon- } \\
\text { den }\end{array}$ & Umur & Pendidikan & $\begin{array}{c}\text { Lama } \\
\text { Berkebun (th) }\end{array}$ & $\begin{array}{c}\text { Bergabung } \\
\text { dengan KUD (th) }\end{array}$ \\
\hline \multicolumn{5}{|c|}{ KUD Lubuk Karya } \\
\hline 1 & 40 & D1 & 4 & 2010 \\
\hline 2 & 40 & SMA/Sederajat & 5 & 2010 \\
\hline 3 & 37 & D3 & 20 & 2010 \\
\hline 4 & 36 & S1 & 20 & 2013 \\
\hline 5 & 34 & SMA/Sederajat & 10 & 2009 \\
\hline 6 & 41 & SMA/Sederajat & 25 & 1998 \\
\hline 7 & 27 & S1 & 0 & 2015 \\
\hline 8 & 41 & D3 & 7 & 2006 \\
\hline 9 & 25 & S1 & 15 & 2017 \\
\hline 10 & 30 & S1 & 6 & 2013 \\
\hline \multicolumn{5}{|c|}{ KUD Kampung Surau } \\
\hline 11 & 49 & SD & 10 & 2009 \\
\hline 12 & 61 & S1 & 11 & 2009 \\
\hline 13 & 54 & SD & 0 & 2009 \\
\hline 14 & 44 & SD & 0 & 2009 \\
\hline 15 & 60 & SMA/Sederajat & 7 & 2009 \\
\hline 16 & 45 & SMA/Sederajat & 5 & 2009 \\
\hline 17 & 47 & SMA/Sederajat & 4 & 2009 \\
\hline 18 & 54 & SD & 7 & 2009 \\
\hline 19 & 46 & SD & 6 & 2009 \\
\hline 20 & 63 & SLTP & 6 & 2009 \\
\hline
\end{tabular}

Dari table 1 dapat di lihat bahwa pengalaman berkebun petani KUD Lubuk karya lebih lama dibandingkan dengan petani KUD Kampung Surau. Kemampuan manajemen pengelolaan juga ditentukan oleh faktor pengalaman. Oleh karena itu 
lama berkebun dapat menjadi sebuah faktor yang sangat mempengaruhi kemampuan pengolaan disamping tingkat pendidikan petani. Petani juga harus senantiasa melakukan aktivitas belajar untuk dapat mengelola kebunannya dengan lebih baik. Pada hakekatnya belajar adalah suatu proses usaha yang dilakukan seseorang untuk memperoleh perubahan tingkah laku yang baru secara keseluruhan ke arah yang lebih baik (Syah, 2008), sebagai hasil pengalamannya sendiri dalam interaksinya dengan lingkungan (Slameto, 2010).

\section{Profil KUD Lubuk Karya dan KUD Kampung Surau}

KUD Lubuk Karya dan KUD Kampung Surau merupakan KUD yang menjalin kerjasama dengan cabang perusahaan Incasy Raya Group yang mempunyai beberapa anak perusahaan di Kabupaten Dharmasraya dengan sistem Bapak Angkat - Anak Angkat. PT. SMP (Selago Makmur Plantation) sebagai Bapak Angkat dari KUD Lubuk Karya dan PT. BPSJ (Bina Pratama Sakato Jaya) sebagai Bapak Angkat KUD Kampung Surau. Adapun tujuan utama dari kerja sama tersebut agar dapat meningkatkan perekonomian rakyat Dharmasraya dan menciptakan perkebunan rakyat dengan kualitas dan produksi yang sama dengan perkebunan inti perusahaan. Namun karena masa perjanjian kerjasama selama 12 tahun telah berakhir yaitu pada tahun 2005 hingga sekarang kedua KUD tersebut telah dikelola secara mandiri oleh masyarakat.

KUD Lubuk Karya merupakan KUD yang mengelola perkebunan rakyat dengan komoditi kelapa sawit yang terdiri dari 4 lokasi lahan perkebunan dengan total luas lahan 3.106 ha dengan masing-masing luasan lahan yang dikelola adalah Lahan Usaha I terletak di Koto Besar sebesar $374 \mathrm{Ha}$, Lahan Usaha II (Koto Besar) sebesar 406 Ha, Sungai Dareh; 173 Ha, Sangir ; 1870 Ha, Bonjol; 283 Ha. Produksi kelapa sawit di KUD Lubuk Karya rata-rata 1,2 ton per hektarnya per bulan. Bibit yang digunakan adalah marihat bersumber dari PPKS Medan.

Pemeliharaan yang dilakukan di KUD Lubuk Karya berupa pemupukan dan pengendalian gulma. Pemupukan dilakukan 6 kali dalam setahun atau satu kali dua bulan. Pupuk yang diberikan berupa pupuk NPK, SP36, dan KCL dengan jumlah yang diberikan $2,3 \mathrm{Kg} / \mathrm{btg} / \mathrm{jenis}$ pupuk, dengan tambahan dolomit dan kieserite dengan upah tenaga kerja Rp. 150.000/ha/semester. Pengendalian gulma dilakukan dengan cara manual dengan menggunakan mesin rumput dan parang serta menggunakan herbisida dengan upah tenaga kerja Rp. 150.000/ha. Pemanenan dilakukan satu kali dalam 15 hari dengan upah tenaga kerja Rp. $150.000 /$ ton.

KUD Lubuk Karya memiliki kerjasama dengan beberapa lembaga keuangan dan mempunyai Sembilan unit usaha. Unit usaha tersebut dinataranya adalah; 1 ) Usaha kebun kelapa sawit, 2) Usaha jasa alat berat, 3) usaha waserda dan transportasi, 4) usaha saprodi, 5) usaha simpan pinjam, 6) usaha pembayaran PLN, 
PBB dan jasa lainnya, 7) usaha peternakan, 8) usaha Pengelolaan pasar tradisional Lubuk Karya dan 9) usaha ramp/timbangan TBS. Permasalahan yang dihadapi adalah kehilangan hasil TBS karena dimaling, penyakit pelepah menguning dan hilangnya sumber pendapatan petani karena saat ini sedang dilakukan replanting.

KUD Kampung Surau mempunyai lahan sebesar 327 Hektar yang terdiri dari 7 kelompok besar. Produksi mencapai 1 ton/ha. Pemeliharaan yang dilakukan di KUD Kampung Surau berupa pruning dan pengendalian gulma. Pruning dilakukan setiap bulannya dengan upah tenaga kerja Rp. 5.000- 7.000/batang. Pengendalian gulma dilakukan dengan menggunakan herbisida dengan upah tenaga kerja Rp. 150.000/ha. Pemanenan dilakukan satu kali 15 (lima belas) hari dengan upah tenaga kerja Rp. 150.000/ton.

KUD Kampung Surau tidak memiliki kerjasama dengan Lembaga keuangan lainnya dan tidak memiliki usaha lainnya selain perkebunan kelapa sawit. Permasalahan yang dihadapi KUD Kampung Surau adalah sarana dan prasarana yang tidak memadai dalam pemeliharaan. Sehingga setelah lepas dari pola plasma, KUD Kampung Surau tidak dapat melakukan pengelolaan dan pemeliharaan yang optimal terhadap kebun kelapa sawitnya. Manajemen pengelolaan belum terstruktur sehingga tidak mempunyai indikator yang jelas dan terukur.

\section{Kolaborasi dalam Pengelolaan Kebun Kelapa Sawit Rakyat}

Perkebunan rakyat pasca plasma sering menghadapi permasalahan baik dalam pengelolaan kebun maupun manajemen keuangan. Dari hasil pengamatan dan wawancara lapangan pada dua KUD yang sudah lepas dari perusahaan induk (dikelola secara mandiri), didapatkan informasi ada KUD yang dapat bertahan dan maju, namun ada KUD yang mengalami permasalahan yang rumit sehingga untuk pemeliharaan kebun sendiri mengalami kesulitan (hasil wawancara dengan informan kunci), sehingga yang dilakukan hanya menunggu jika ada batuan dari pemerintah dan pihak lain.

Kolaborasi antar aktor didalam pengelolaan kebun kelapa sawit rakyat pasca plasma sangat dibutuhkan. Kolaborasi berupa interaksi yang saling mengisi antara satu pihak dengan pihak lainnya dapat meningkatkan kemampuan petani dalam pengelolaan kebun kelapa sawit yang lebih baik. Jika dibandingkan dengan KUD Lubuk Karya, dengan kerjasama yang dilakukan bersama Lembaga keuangan lainnya, kolaborasi yang baik antara anggota KUD, pengurus, dan pihak-pihak eksternal dapat meningkatkan kemampuan KUD yang dibuktikan dengan bertumbuhnya unit-unit usaha lain selain kebun kelapa sawit. Dengan demikian sumber pendapat petani sebagai anggota KUD tidak bertumpu pada kebun kelapa sawit saja, akan tetapi dapat ditingkatkan dengan adanya unit-unit usaha lainnya.

Dari pengamatan dilapangan ada tujuh aktor penting yang harus selalu menjaga koordinasi dan komunikasi dalam konsep kolaborasi untuk pengelolaan 
kebun rakyat yang lebih baik yaitu: petani, pengurus KUD, penyuluh lapangan, pemerintah, perusahaan (sebagai bapak angkat pada pola plasma), pedagang pengumpul (toke), pabrik (pemilik kilang). Perlu kolaborasi satu sama lain sehingga petani memperoleh pengetahuan yang lebih terkait dengan pengelolaan kebun kelapa swit yang baik. Sehingga masalah rendahnya produktivitas tidak lagi menjadi permasalahan. Kualitas dan kuantitas hasil dapat ditingkatkan melalui transfer pengetahuan antara satu aktor dengan aktor lainnya. Hal ini di dukung oleh pendapat Menurut Purnomo et al., (2016) bahwa ada beberapa aktor dalam struktur perkebunan kelapa sawit, pemilik kilang merupakan aktor ekonomi terkuat (1), disusul oleh pemilik korporasi kebun (2), pemilik PKS (3) dan pemilik kebun sawit skala sedang (4) disusul oleh agen CPO (5) dan Pengklaim lahan (6) dan Penebas lahan (7). Petani sawit, terutama petani swadaya, adalah aktor yang lemah dalam rantai nilai sawit.

\section{KESIMPULAN DAN SARAN}

Dampak perkebunan kelapa sawit terhadap perekonomian desa pada KUD Lubuk Karya lebih besar dibandingkan dengan KUD Kampung Surau dibuktikan dengan unit-unit usaha yang berkembang. Kolaborasi antar aktor didalam pengelolaan kebun kelapa sawit rakyat pasca pola plasma lebih optimal dilakukan pada KUD Lubuk Karya dibandingkan dengan KUD Kampung Surau.

Perlu kolaborasi antar aktor dalam pengelolaan perkebunan kelapa sawit rakyat yang lebih baik. Melalui kolaborasi diharapkan bahwa petani sebagai aktor yang paling lemah posisinya diantara aktor lainnya mendapatkan pengetahuan yang lebih baik sehingga dapat mengelolaan perkebunannya dengan lebih baik sehingga produktivitas meningkat.

\section{DAFTAR PUSTAKA}

Afifuddin, S., Kusuma, SI. 2007. Analisis Struktur Pasar CPO: Pengaruhnya terhadap pengembangan ekonomi wilayah Sumater Utara. Jurnal Perencanaan dan Pengembangan Wilayah. Vol. 2 No. 3. April 2007. Hal 124 $-136$.

Alwarritzi, Nanseki, Chomei, 2015. Analysis of the factors influencing the technical efficiency among oil palm smallholder farmers in Indonesia. Proc. Environ. Sci. 28, 630e638. https://doi.org/10.1016/j.proenv.2015.07.074.

Badan Pusat Statistik Indonesia. 2017. Statistik Kelapa Sawit Indonesia 2017. Badan Pusat Statistik.

Badan Pusat Statistik Dharmasraya. 2018. Dharmasrya Dalam Angka 2018. Badan Pusat Statistik. 
Dillenbourg, P. (1999). What do you mean by 'collaborative learning?' In P. Dillenbourg (Ed.), Collaborative-learning: Cognitive and Computational Approaches (pp.1-19). Oxford: Elsevier.

Pahan, I. 2010. Kelapa Sawit Manajemen Agribisnis dari Hulu Hingga Hilir. Penebar Swadaya, Jakarta. 411 hal.

Roschelle, J. (1992) Learning by collaborating: Convergent conceptual change. Journal of the Learning Sciences, 2, 235-276.

Roschelle, J. \& Teasley, S. D. (1995). The construction of shared knowledge in collaborative problem-solving. In C.E. O'Malley (Ed.), Computer-supported collaborative learning (pp. 69-97). Berlin: Springer-Verlag.

Saner, H., McCaffrey, D., Stecher, B., Klein, S., \& Bell, R. (1994). The effects of working in pairs in science performance assessments. Educational Assessment, 2(4), 325-338.

Slameto. 2003. Belajar dan Faktor-Faktor Yang Mempengaruhi. Jakarta: Rineka Cipta.

Syah, Muhibbin. 2003. Psikologi Belajar. Jakarta : Raja Grafindo Persada

Syahza, Almasdi. 2011. Percepatan Ekonomi Pedesaan Melalui Pembangunan Perkebunan Kelapa Sawit. Jurnal Ekonomi Pembangunan Vol.12 hlm.297310.

Tudge, J. R. H. (1992). Processes and consequences of peer collaboration: A Vygotskian analysis. Child Development, 63(6), 1364-1379.

Webb, N.M. (1991). Task-related verbal interaction and mathematical learning in small groups. Research in Mathematics Education, 22(5), 366-389. 